\title{
A study on relationship between investment opportunities and earnings: A corporate life cycle investigation
}

\author{
Mona Abednazari ${ }^{\mathbf{a}^{*}}$ and Iraj Noravesh ${ }^{\mathrm{b}}$
}

Department of Accounting, University of Tehran, Kish international campus, Iran Department of Accounting, University of Tehran, Tehran, Iran

\begin{tabular}{|c|c|}
\hline CHRONICLE & ABSTRACT \\
\hline $\begin{array}{l}\text { Article history: } \\
\text { Received January 18, } 2013 \\
\text { Received in revised format } \\
\text { 2 June } 2013 \\
\text { Accepted } 5 \text { June } 2013 \\
\text { Available online } \\
\text { June } 102013 \\
\text { Keywords: } \\
\text { Investment opportunities } \\
\text { Earnings response coefficient } \\
\text { Life cycle }\end{array}$ & $\begin{array}{l}\text { Intrinsic value of a firm depends on its financial and investing decisions. Market reacts } \\
\text { differently to firms with different level of investment opportunities. A firm's age and current } \\
\text { stage of life cycle affect its future investment opportunities. Examining a sample of Tehran } \\
\text { Stock Exchange for the period of 2006-2010, this study examines the relationship between } \\
\text { investment opportunities and earnings according to corporate life cycle. } \\
\text { Results suggest a significant association between investing activities and earnings response } \\
\text { coefficient. Additionally, the results indicate that the explanatory power of the relationship } \\
\text { between investment opportunities and earnings varies by corporate life cycle. Growth firms } \\
\text { indicate stronger relation than decline firms do. }\end{array}$ \\
\hline
\end{tabular}

\section{Introduction}

Rational decision making requires relevant and reliable data. Accounting as an information system for fulfilling requirements of various users, especially investors, is a valuable source of information. Thus, it is expected that the outcome of accounting information system is of quality and relevance. Future investment opportunities reflected to investors by means of financial statement items are important to many users.

Investment opportunities constitute an essential part of firm value (Miller \& Modigliani, 1961; Dixit \& Pindyck, 1994). Investment opportunities are believed as better future and are reflected in valuation of firms. However, as Hultazen and Watts (2001) state, empirical research based on accounting valuation to a large extent has ignored growth. Growth potential relies on investment opportunities and life cycle. If earnings are associated with change in investment opportunities, then providing evidence of this relationship can be useful in firm valuation.

*Corresponding author.

E-mail addresses: mona.abednazari@yahoo.com (M. Abednazari) 
Firms with investment opportunities are anticipated to be valued differently in market. It is also argued that informativeness of investment opportunities is communicated to market through such accounting variables as earnings, operating cash flows and accruals, and thus these variables are of various informativeness in firms with different investment opportunities. On the other hand, a firm's age and current stage of life cycle affect its future investment opportunities. Therefore, two main questions in this study are:

1) Do future investment opportunities affect informativeness of earnings?

2) Does the relationship between investment opportunities and earnings depend on the stage of life cycle?

\section{Background}

There has been a massive literature on the relationship between accounting numbers and firm value. Ball and Brown (1968) demonstrated the relationship between accounting earnings and stock prices. This specifies that accounting earnings is of value relevance. Different studies recommend numerous factors to explain the heterogeneous reaction of market to unexpected changes in accounting earnings. The riskier the expected return of a security, the less the value of the security to risk-averse and rational investors whose utility increases with an increase in the expected return and a reduction in risk. Since investors believe current period earnings as indicative of more future profitability and return, the riskier the return, the less investors react to a certain extent of unexpected earnings. Good or bad news embedded in current period earnings can specify future growth of a firm, thus a bigger earnings response coefficient is anticipated. However, it might be criticized that earnings based on historical cost cannot provide information about future growth.

Billings (1999) documented that firms with higher debt-to-equity ratio could indicate less earnings response coefficient. It is anticipated that market is less concerned about default risk for firms with high earnings growth, as earnings growth will secure outstanding debts. Given that, a higher earnings response coefficient in business models without outstanding debt or less outstanding debt could be due to high earnings growth not less leverage. However, Billings (1999) suggested a reverse relationship between earnings response coefficient and leverage.

Collins and Kothari (1989) argued that "ceteris paribus, the future earnings and dividend streams will be larger in the presence of growth opportunities than absent such opportunities". Therefore, if current earnings provide information about investment opportunities, investment opportunities must be directly associated with earnings response coefficient. Biddle and Seow (1991) reported a positive (negative) association between earnings response coefficient (return response coefficient) and investment opportunities. Ahmed (1994) reported that accounting earnings reflects information about future economic earnings from firms' current assets. In contrast to prior research, his findings also suggested that accounting earnings would not provide much information about growth opportunities.

Amir and Lev (1996) demonstrated that financial information such as earnings, book value, and cash flows if considered individually were to a large extent irrelevant for security valuation purposes. However, when considered besides non-financial information, earnings can contribute to explain security prices. Krisnawati (2006) concluded that there was no significant association between value relevance of operating cash flow and accruals on one hand and investment opportunities on the other. He reported no significant positive relationship between stock price and operating cash flow. Krisnawati finally suggested that not all his independent variables could be considered as contributing factors for firms' growth in order to explain stock prices fluctuations.

Kumar and Krishnan (2008) demonstrated that at lower levels of investment opportunities the value relevance of cash flow from operations could increase with investment opportunities. When investment opportunities are high, as investment opportunities increases the value relevance of 
accruals will decrease. The trends of value association of accruals at low levels of investment opportunities and value relevance of cash flow from operations at high levels of investment opportunities were not statistically substantial. Therefore, earnings response coefficient first directly and then inversely was associated with investment opportunities. Liang et al. (2011) recommended that if dividend were not distributed to save cash for more desirable investments, investors would not necessarily view it as bad news. Market punishes firms for not distributing dividend only if the perspective of future investment would not desirable. Additionally, positive relationship between investment opportunities and unexpected stock return around earnings announcement would be greater when information asymmetry between management and other market participants were low.

Aharony et al. (2006) reported that stage the explanatory power of factors based on cash flows was greater in growth and in maturity and decline stages the explanatory power of accruals-based factors is higher. Kallunki and Silvola (2008) stated that due to change in management information requirements, the extent of application of activity based costing changes across life cycle stages. Activity based costing is more applied in maturity and rebirth stages than in growth stage.

Babajani et al. (2011) stated that as investment opportunities increase, value relevance of earnings first declines and then increases. Prior research recommended that as investment opportunities grow, value relevance of cash flow from operations and accruals declines. This means that investors view accounting earrings as reliable and relevant only at low levels of investment opportunities. At higher levels of investment opportunities they consider other sources of information in their valuation. Previous studies also recommended that investors view earnings components as noisy criteria and thus they would not employ these figures in their valuation decisions. Ramezani (2011) provided evidence consistent with earnings response coefficient increasing with investment opportunities (in line with information growth hypothesis), while value relevance of other three variables, i.e. earnings persistence, accruals, and operating cash flow does not increase (in line with noisy measure hypothesis). Karami and Omrani (2010b) reported that for firms in growth stage investors put more emphasis on net operating assets and abnormal operating income as compared with those in maturity and decline stages. Their results also disclosed that in growth and maturity stages, investors emphasise on net operating assets and abnormal operating income of conservative firms, compared with firms using more aggressive accounting methods, and the reverse was the case for decline stage.

\section{Research Hypotheses}

To answer the questions discussed earlier, the following hypotheses are set:

$H_{1}$ : Investment opportunities are associated with earnings response coefficient.

$\mathrm{H}_{2}$ : The relationship between investment opportunities and earnings varies significantly across life cycle stages.

\subsection{Hypotheses Testing and Variables Measurement}

This study employs the following model used by Jones (1997) and Kumar et al. (2008):

$R_{i t}=\beta_{0}+\beta_{1} E_{i t}+\beta_{2} \Delta E_{i t}+\beta_{3} I O S_{i t}+\beta_{4} I O S * E_{i t}+\beta_{5} B e t a_{i t}+\varepsilon_{i t}$

$R_{i t}$ : Normal return for stock $i$ for period $t$ which is calculated as following:

$R_{i, t}=\frac{\left(P_{i, t}-P_{i, t-1}+D_{i, t}\right)}{P_{i, t-1}}$

Note that required adjustments are made to account for the impact of capital increase and resources used for capital increase. 
The normal return is calculated for four periods including last 3 three-month periods before the fiscal year end and the first three-month period of the next year, to make sure that dividend distribution and cash flows during the test period are considered.

$E_{i t}$ : Current operating income scaled by market value of equity at the beginning of the period. Market value of equity at the beginning of the period is the multiplication of number of common share by stock price on the last day of prior fiscal year.

$\Delta E_{i t}$ : Change in operating income for stock $i$ for period $t$ relative to period $t-1$.

$I O S_{i t}$ : Variable indicating investment opportunities during the fiscal year which is measured by market to book value of stock. This ratio has been used by Collins \& Kothari (1989), Biddle \& Seow (1991), Gaver \& Gaver (1993), Hrikumar \& Harter (1995), and Jones (1997, 2001) to measure investment opportunities.

$B e t a_{i t}$ : Measure of systematic risk which is included into the model as a control variable Kumar \& Krishnan (2008). Beta is estimated by the slope of market model regression for stock daily return $\left(R_{i t}\right)$ and market daily return $\left(R_{m t}\right)$ for one year period beginning from the fourth month of the period under investigation.

The term $\beta_{1} E_{i t}+\beta_{4} I O S * E_{i t}$ denotes earnings response coefficient.

To test $\mathrm{H}_{2}$, all firms in the sample are grouped by their life cycle stage and the above model is run for the first and last group. Then, using Cramer Z-test, coefficients of determination of the first and third groups are compared.

\section{Life Cycle}

Various models have been implemented in the accounting and finance literature to determine corporate life cycle stage. One of the most commonly-used models is recommended by Anthony and Ramesh (1992). They group firms by three variables: sales growth, capital expenditures, and firm age. This research uses the three variables to group firms by their life cycle stage. To this end, we follow the methodology suggested by Park \& Chen (2006) as following:

1. Sales growth, capital expenditure, and firm age are calculated for each firm-year.

2. Industry quintiles are calculated for each of the above variables for each firm-year. The score of each firm-year is assigned from 1 to 5 using the following table.

\begin{tabular}{lccc}
\hline Quintiles & Sales Growth $(\mathrm{SG})$ & Capital Expenditure $(\mathrm{CE})$ & Firm age \\
\hline $1^{\text {st }}$ quintile & 1 & 1 & 5 \\
$2^{\text {nd }}$ quintile & 2 & 2 & 4 \\
$3^{\text {rd }}$ quintile & 3 & 3 & 3 \\
$4^{\text {th }}$ quintile & 4 & 4 & 2 \\
$5^{\text {th }}$ quintile & 5 & 5 & 1 \\
\hline
\end{tabular}

3. Each firm-year is now assigned a combined score which can be used to classify firm into growth, maturity, and decline firms according to the following scheme:

a. Growth stage if the score falls between 12 and 15 .

b. Maturity stage if the score falls between 7 and 11 .

c. Decline stage if the score falls between 3 and 6 .

Sales growth, capital expenditure, and firm age are calculated as following:

$$
\mathrm{SG}_{\mathrm{t}}=\left\{1-\left(\text { Sale }_{\mathrm{t}} / \text { Sale }_{\mathrm{t}-1}\right)\right\} \times 100
$$




$$
C E_{t}=(\text { increase }(\text { decrease }) \text { in fixed assets during the period/firm market value }) \times 100
$$

AGE: The difference between the year in question and the year of foundation of the firm.

\section{Sample and Data}

This study employs non-probability sampling. In our non-probability sampling plan, to be selected in the sample firms must:

1. be accepted in Tehran Stock Exchange by $20^{\text {th }}$ of March 2006 (end of first period according to Persian Calendar) and they must have the same year end date.

2. not have changed their fiscal year during the period under investigation (2006-2010).

3. have been active during the period under investigation and their stocks have been traded in the market.

4. have available required financial information for the period under study.

5. not be an investment or financial firm.

Having applied the above criteria, we are left with 82 firms. Also of importance is the fact that some firm-years have been excluded from the final sample due to unavailability of required data or nonnormality of the distribution of data.

\section{Descriptive Analysis}

Table 1 indicates that the mean return of the sample firms is $13.6 \%$, with a maximum of $188 \%$ and a minimum of $-72.3 \%$. Mean of operating income to market value of equity at the beginning of period is 0.254 . Weighted mean of market-to-book ratio, the measure of investment opportunities, is greater than 1 (about 2.7) which suggests that on average mean of stock price in our sample is greater than book value, with a maximum of 26 .

On average, change in operating income is $3.51 \%$ which is close to its maximum, i.e. $3.36 \%$.

\section{Table 1}

descriptive statistics

\begin{tabular}{lllllll}
\hline & $\begin{array}{l}\text { Stock return } \\
(\mathrm{R})\end{array}$ & $\operatorname{Beta}(\beta)$ & $\begin{array}{l}\text { Investment } \\
\text { opportunities }(\mathrm{IOS})\end{array}$ & $\begin{array}{l}\text { Operating } \\
\text { income }(\mathrm{E})\end{array}$ & $\begin{array}{l}\text { Change in operating } \\
\text { income }(\Delta \mathrm{E})\end{array}$ & IOS*E \\
\hline Mean & 0.136 & 0.2109 & 2.6990 & 0.2538 & 0.0351 & 0.5648 \\
Median & 0.145 & 0.1600 & 1.8500 & 0.2132 & 0.0211 & 0.3651 \\
Maximum & 1.8860 & 14.6300 & 26.1700 & 3.7952 & 3.3620 & 15.4550 \\
Minimum & -0.7230 & -7.9500 & -0.1200 & -2.2426 & -1.9041 & -2.1563 \\
$\begin{array}{l}\text { Standard } \\
\text { deviation }\end{array}$ & 0.4790 & 2.0561 & 3.1234 & 0.3238 & 0.2933 & 1.0402 \\
Skewness & 3.1762 & 0.6012 & 3.7724 & & & 8.2738 \\
Kurtosis & 17.8080 & 12.6730 & 21.4730 & 2.1908 & 2.6186 & 104.9500 \\
Jarque-Bera & 0.06 & 0.82 & 0.38 & 46.8750 & 50.7990 & 0.54 \\
Significance & 0.92 & 0.66 & 0.83 & 0.87 & 0.62 & 0.19 \\
\hline
\end{tabular}

Considering the significance level of Jarque-Bera stated in Table 1, since the significance level is greater than $5 \%$, the null hypothesis of normality of distribution for all variables cannot be rejected and hence the distribution of variables are considered as normal. Correlation between research variables is presented in Table 2 . The results indicate that return is positively correlated to operating income, change in operating income, and investment opportunities, but negatively correlated to beta. Return shows the highest correlation with investment opportunities (0.226) and lowest correlation with change in operating income. Investment opportunities are positively correlated to beta and negatively correlated to operating income. 
Table 2

Correlation between variables

\begin{tabular}{|c|c|c|c|c|c|}
\hline & Return & Operating income & Change in operating income & Investment opportunities & Beta \\
\hline Return & 1 & & & & \\
\hline Operating income & 0.032 & 1 & & & \\
\hline $\begin{array}{l}\text { Change in } \\
\text { operating income }\end{array}$ & 0.014 & 0.706 & 1 & & \\
\hline $\begin{array}{l}\text { Investment } \\
\text { opportunities }\end{array}$ & 0.225 & -0.076 & 0.068 & 1 & \\
\hline Beta & -0.088 & -0.050 & -0.006 & 0.140 & 1 \\
\hline
\end{tabular}

\section{Test of First Hypothesis}

First hypothesis states that investment opportunities are associated with earnings response coefficient. The following model is used to test this hypothesis:

$$
R_{i t}=\beta_{0}+\beta_{1} E_{i t}+\beta_{2} \Delta E_{i t}+\beta_{3} I_{O S}+\beta_{4} I O S * E_{i t}+\beta_{5} B e t a_{i t}+\varepsilon_{i t}
$$

To select the appropriate model, we first conduct Chow test (Restrictive F-test) to choose from pooled model and fixed effect model. The results from Chow test is presented in Table 3.

\section{Table 3}

Chow test results

Time fixed effects test

\begin{tabular}{lccc}
\hline Test of effects & Statistics & Degrees of freedom & Significance level \\
\hline F & 1.473885 & 4383 & 0.2094 \\
Chi Square & 6.003381 & 4 & 0.1989 \\
\hline
\end{tabular}

As can be seen from Table 3, the null hypothesis of equality of intercepts cannot be rejected; therefore pooled model is selected as the preferable model. If fixed effects model was chosen, fixed effect model would have been compared to random effects model using Hausman test. Results of estimation model are shown in Table 4.

Table 4

Model estimation results

\begin{tabular}{lcccc}
\hline Variables & Coefficients & Standard error & T statistics & Significance level \\
\hline Intercept & 2031.686 & 914.2696 & 2.222196 & 0.0269 \\
Operating income (E) & 23538.44 & 3561.109 & 6.609862 & 0.0000 \\
Change in operating income & -1357.843 & 9168.449 & -2.148100 & 0.0223 \\
$(\Delta \mathrm{E})$ & & & 2.292169 & 0.0203 \\
Investment opportunities (IOS) & 2861.880 & 9795.277 & 3.445479 & 0.0006 \\
IOS*E & 3102.574 & 900.4769 & -0.603185 & 0.5467 \\
Beta & -1655.727 & 2744.973 & \\
\hline Coefficient of determination $\left(R^{2}\right)$ & 0.355497 & Dependant variable: stock return & \\
Adjusted $R^{2}$ & 0.343294 & Method: least square with panel data & & \\
F statistics & 4.547831 & Time period: 2006-2010 & & \\
F statistics significance level & 0.000484 & Number of firms: 82 & \\
Durbin-Watson statistic & 1.704068 & Number of firm-years: 410 & & \\
\hline
\end{tabular}

According to Table 4, since significance level of F statistic $(0.000484)$ is less than 0.05 , it can be concluded that goodness of fit indicator is significant and hence the regression is significant. DurbinWatson statistic is almost 1.0704 which rejects the existence of autocorrelation between residuals. Coefficient of determination is about 0.355 which indicates that $35 \%$ of changes in dependent variable (stock return) can be explained by independent variables. In other words, explanatory variables predict $35 \%$ of stock return. As the coefficients denote, there is a significantly positive relationship between investment opportunities and the interaction between stock price and investment opportunities. This implies that earnings response coefficient (IOS + IOS*E) is significantly 
positively related to investment opportunities. Since both coefficients of this variable, i.e. earnings response coefficient, are positive, change in earnings and investment opportunities are associated with a change of similar direction in stock return. Therefore, the first hypothesis cannot be rejected, i.e. investment opportunities are associated with earnings response coefficient.

\section{Test of Second Hypothesis}

Second hypothesis states that the relationship between investment opportunities and earnings varies significantly across life cycle stages. To test this hypothesis all sample firms are classified into three groups based on their life cycle stage, and the model is run for first and third groups. Coefficient of determination is then compared for the first and third group. The model is first run for firms with low life cycle score, i.e. firms in the decline stage. Again to select the appropriate model, we first conduct Chow test (Restrictive F-test) to choose from pooled model and fixed effect model. The results from Chow test for firms with low life cycle score is presented in Table 5 as follows,

\section{Table 5}

Chow test results for firms with low life cycle score

Time fixed effects test

\begin{tabular}{lccc}
\hline Test of effects & Statistics & Degrees of freedom & Significance level \\
\hline F & 0.304299 & 454 & 0.8738 \\
Chi Square & 1.426584 & 4 & 0.8396 \\
\hline
\end{tabular}

As can be seen from Table 5, the null hypothesis of equality of intercepts cannot be rejected; therefore pooled model is selected as the preferable model. Results of estimation model for firms with low life cycle score are shown in Table 6.

\section{Table 6}

Model estimation results for firms with low life cycle score

\begin{tabular}{|c|c|c|c|c|}
\hline Variables & Coefficients & Standard error & T statistics & Significance level \\
\hline Intercept & 17483.05 & 18560.59 & 0.941945 & 0.3501 \\
\hline Operating income $(\mathrm{E})$ & 28948.30 & 44168.63 & 2.655404 & 0.0248 \\
\hline $\begin{array}{l}\text { Change in operating } \\
\text { income }(\Delta \mathrm{E})\end{array}$ & 31979.73 & 38549.54 & 2.829575 & 0.0202 \\
\hline $\begin{array}{l}\text { Investment } \\
\text { opportunities (IOS) }\end{array}$ & 16952.62 & 4842.128 & 3.501067 & 0.0009 \\
\hline IOS*E & 14690.89 & 9841.277 & 2.002783 & 0.0409 \\
\hline Beta & -2889.295 & 3399.696 & -0.849869 & 0.3989 \\
\hline \multicolumn{2}{|c|}{ Coefficient of determination $\left(R^{2}\right) \quad 0.309811$} & \multicolumn{2}{|c|}{ Dependant variable: stock return } & \\
\hline Adjusted $R^{2}$ & 0.250312 & \multirow{2}{*}{\multicolumn{2}{|c|}{$\begin{array}{l}\text { Method: least square with panel data } \\
\text { Time period: } 2006-2010\end{array}$}} & \\
\hline F statistics & 5.206991 & & & \\
\hline F statistics significance level & 0.000515 & \multicolumn{2}{|l|}{$\begin{array}{l}\text { Time period: } 2006-2010 \\
\text { Number of firms: } 14\end{array}$} & \\
\hline Durbin-Watson statistic & 1.829140 & \multicolumn{2}{|l|}{ Number of firm-years: 70} & \\
\hline
\end{tabular}

As can be seen from Table 6, since significance level of F statistic $(0.000515)$ is less than 0.05 , it can be concluded that goodness of fit indicator is significant and hence the regression is significant. Durbin-Watson statistic is almost 1.829 which rejects the existence of autocorrelation between residuals. Coefficient of determination is about 0.309. Comparing decline firms and all firms in the sample indicates that coefficient of determination of firms in decline stage (31\%) is less than that of all firms (35\%) which denotes implies that decline firms have lower investment opportunities and this fact seems to be well perceived by market.

As the coefficients denotes, investment opportunities are significantly positively related to interaction between stock price and investment opportunities. This implies that there is significant positive relationship between earnings response coefficient and investment opportunities. In this section the model is run for firms with high life cycle score, i.e. growth firms. Results from Chow test for firms with high life cycle score is presented in Table 7. 


\section{Table 7}

Chow test results for firms with high life cycle score

Time fixed effects test

\begin{tabular}{lccc}
\hline Test of effects & Statistics & Degrees of freedom & Significance level \\
\hline F & 0.949376 & 453 & 0.4429 \\
Chi Square & 4.359628 & 4 & 0.3595 \\
\hline
\end{tabular}

According to Table 7, the null hypothesis of equality of intercepts cannot be rejected; therefore pooled model is selected as the preferable model. Results of estimation model for firms with high life cycle score are shown in Table 8.

\section{Table 8}

Model estimation results for firms with high life cycle score

\begin{tabular}{lcccc}
\hline Variables & Coefficients & Standard error & T statistics & Significance level \\
\hline Intercept & 9896.613 & 4992.717 & 1.982210 & 0.0523 \\
Operating income $(\mathrm{E})$ & 29661.67 & 24118.65 & 2.229823 & 0.0238 \\
Change in operating income $(\Delta \mathrm{E})$ & -21180.09 & 20733.28 & -2.011550 & 0.0313 \\
Investment opportunities $(\mathrm{IOS})$ & 1630.674 & 1014.554 & 2.607282 & 0.0235 \\
IOS*E & 3885.891 & 5688.804 & 2.683077 & 0.0203 \\
Beta & -1350.326 & 1269.012 & -1.064076 & 0.2918 \\
Coefficient of determination $\left(R^{2}\right)$ & \multicolumn{5}{c}{0.390446} \\
\hline Adjusted $R^{2}$ & 0.375538 & Dependant variable: stock return \\
F statistics & 4.272951 & Method: least square with panel data \\
F statistics significance level & 0.001203 & Time period: 2006-2010 \\
Durbin-Watson statistic & 1.840736 & Number of firms: 14 Number of firm-years: 70 &
\end{tabular}

Since significance level of F statistic (0.001203) is less than 0.05 , it can be concluded that goodness of fit indicator is significant and hence the regression is significant. Durbin-Watson statistic is almost 1.841 which rejects the existence of autocorrelation between residuals. Coefficient of determination is about 0.39. Comparing growth firms and all firms in the sample indicates that coefficient of determination of growth firms $(39 \%)$ is less than that of all firms $(35 \%)$ which denotes implies that growth firms have higher investment opportunities and this fact seems to be well perceived by market. As the coefficients indicate, investment opportunities are significantly positively associated with interaction between stock price and investment opportunities, and there is a significantly negative relationship between change in operating income and stock return. Comparing the coefficients of determination of the two groups of firms with high life cycle score $(39 \%)$ and those with low life cycle score (31\%) reveals that the explanatory power of the relationship between investment opportunities and earnings for firms with low life cycle score is lower. Accordingly, the explanatory power of the relationship between investment opportunities and earnings is greater for growth firms relative to decline firms. When a single model is intended to be run for two samples from two separate independent populations in order to compare the resultant coefficient of determination, Cramer Z-test should be used. The Cramer Z-statistic is computed as following:

$$
Z=\frac{R_{1}^{2}-R_{2}^{2}}{\sqrt{\sigma_{R_{1}^{2}}^{2}+\sigma_{R_{2}^{2}}^{2}}}
$$

Where $R_{1}^{2}$ and $R_{2}^{2}$ are coefficients of determination of the model for first and second samples, and $\sigma_{R_{1}^{2}}^{2}$ and $\sigma_{R_{2}^{2}}^{2}$ are the variance of coefficients of determination for the two samples under investigation.

Now, using Cramer Z-test, the significance of the difference between coefficient of determination for growth firms and decline firms is examined. The results are presented in Table 9.

\section{Table 9}

Cramer Z-test results

Cramer Z-statistic


Cramer Z-test results indicate that the difference between coefficient of determination for growth firms and decline firms is significant. Hence, the second hypothesis cannot be rejected, i.e. the relationship between investment opportunities and earnings varies significantly across life cycle stages.

\section{Discussion and Conclusion}

Considering the regression model coefficient of the first hypothesis, there is a significantly positive relationship between stock return and three independent variables, i.e. investment opportunities, interaction between investment opportunities and operating income, and operating income. In other words, earnings response coefficient is significantly positively related to investment opportunities. The results of the first hypothesis are consistent with findings of prior studies including Collins \& Kothari (1989), Biddle \& Seow (1991), Hrikumar \& Harter (1995), and Jones (1997). However, our results are different form Ahmed (1994) who documents a negative relationship between earnings response coefficient and investment opportunities. He argues that the expected negative relationship is due to application of accounting conventions such as conservatism which lowers the timeliness of earnings, relative to stock prices, in reflecting the value relevance of investment opportunities.

Model results reveal that there is a significant positive relationship between investment opportunities and interaction of investment opportunities and stock return for decline firms. Comparing decline firms and all firms in the sample reveals that coefficient of determination of decline firms (31\%) is less than that of all firms (35\%). Coefficients of determination for growth firms and all firms are 39\% and $35 \%$, respectively. This reveals that growth firms have high investment opportunities. Comparing the coefficients of determination of growth and decline firms suggests that the explanatory power of the relationship between investment opportunities and earnings is lower for decline firms relative to growth firms. In contrast, the explanatory power of the relationship between investment opportunities and earnings is higher for growth firms compared to decline firms. Cramer Z-test results indicate that the difference between coefficient of determination for growth firms and decline firms is significant. Therefore, the relationship between investment opportunities and earnings varies significantly across life cycle stages. Two implications can be derived from our findings:

1. Given the results for the first hypothesis that investment opportunities is significantly related to earnings response coefficient, and since earnings together with investment opportunities is of more value relevance, it is recommended that investors rethink the reliance they put on earnings in their valuations and decisions.

2. Results for the second hypothesis indicate that the relationship between investment opportunities and earnings varies significantly across life cycle stages. Furthermore, the explanatory power of the relationship between investment opportunities and earnings is higher for growth firms compared to decline firms. Therefore, investors are recommended to consider corporate life cycle in their valuations and decisions.

\section{References}

Aharony, J., Falk, H., \& Yehuda, N. (2006). Corporate Life Cycle and the Relative Value-Relevance of Cash Flow versus Accrual Financial Information.2003-07-15)[2008-08-30].

Ahmed, A. S. (1994). Accounting earnings and future economic rents: An empirical analysis. Journal of Accounting and Economics, 17(3), 377-400.

Amir, E., \& Lev, B. (1996). Value-relevance of nonfinancial information: The wireless communications industry. Journal of accounting and economics,22(1), 3-30.

Anthony, J. H., \& Ramesh, K. (1992). Association between accounting performance measures and stock prices: A test of the life cycle hypothesis. Journal of Accounting and Economics, 15(2), 203227. 
Babajani, J., Bulu, Q., \& Alizadeh, A, (2011). The relationship between investment opportunities and value relevance of operating cash flow and accruals. Stock Exchange Journal, 13(1).

Ball, R., \& Brown, P. (1968). An empirical evaluation of accounting income numbers. Journal of accounting research, 159-178.

Barth, M. E., Beaver, W. H., \& Landsman, W. R. (2000). The relevance of value relevance research. Working paper. Journal of Accounting and Economics Conference.

Bernard, V. L., \& Stober, T. L. (1989). The nature and amount of information in cash flows and accruals. Accounting review, 64, 624-652.

Biddle, G. C., \& Seow, G. S. (1991). The estimation and determinants of associations between returns and earnings: evidence from cross-industry comparisons. Journal of Accounting, Auditing \& Finance, 6(2), 183-232.

Billings, B. K. (1999). Revisiting the relation between the default risk of debt and the earnings response coefficient. The Accounting Review, 74(4), 509-522.

Collins, D. W., \& Kothari, S. P. (1989). An analysis of inter-temporal and cross-sectional determinants of earnings response coefficients. Journal of Accounting and Economics, 11, 143181.

Financial Accounting Standards Board (FASB). 1978. Objective of Financial Reporting by Business Enterprises. Statement of Financial Accounting Concepts No.1. Stamford, CT: Financial Accounting Standards Board.

Financial Accounting Standards Board (FASB). 1980. Qualitative characteristics of accounting information. Statement of Financial Accounting Concepts No.2. Stamford, CT: Financial Accounting Standards Board.

Gaver, J. J., \& Gaver, K. M. (1993). Additional evidence on the association between the investment opportunity set and corporate financing, dividend, and compensation policies. Journal of Accounting and Economics, 16(1), 125-160.

Harikumar, T., \& Harter, C. I. (1995). Earnings response coefficient and persistence: New evidence using Tobin's Q as a proxy for persistence. Journal of Accounting, Auditing \& Finance, 10(2), 401-418.

Jones, Jefferson P. (2001). The implications of firms' investment opportunities for the valuation of cash flows from investing activities. Advances in Accounting, 18, 169-193.

Kallunki, J. P., \& Silvola, H. (2008). The effect of organizational life cycle stage on the use of activity-based costing. Management Accounting Research, 19(1), 62-79.

Karami, G., \& Omrani, H. (2010a). The effect of corporate life cycle on relevance of risk and performance measures. Journal of Accounting and Finance Studies, 3(5), 49-64.

Karami, G., \& Omrani, H. (2010b). The effect of corporate life cycle and conservatism on firm value. Accounting and Auditing Studies, 59, 79-96.

Krisnawati, A. (2006), The value relevance of cash flow and accruals: The role of investment. Islamic University of Indonesia.

Kumar, K. R., \& Krishnan, G. V. (2008). The value-relevance of cash flows and accruals: The role of investment opportunities. The Accounting Review, 83(4), 997-1040.

Liang, H., Moreau, L., \& Park, J. C. (2011). Investment opportunities and dividend omissions. Journal of Business Research, 64(10), 1108-1115.

Park, Y., \& Chen, K. H. (2011). The Effect Of Accounting Conservatism And Life-Cycle Stages On Firm Valuation. Journal of Applied Business Research (JABR), 22(3).

Ramazani, F. (2011). The role of investment opportunities in valuation of earnings, earnings persistence, and operating cash flows. Master's thesis. Islamic Azad University Science and Research Branch.

Scott, W. R. (2003). Financial Accounting Theory. $3^{\text {rd }}$ ed. Prentice Hall pub.

Sloan, R. G. (1996). Do stock prices fully reflect information in accruals and cash flows about future earnings?. Accounting Review, 289-315. 